Editorial

\title{
Special Issue: Environmental Barrier Coatings
}

\author{
Kang N. Lee \\ NASA Glenn Research Center, Cleveland, OH 44135, USA; ken.k.lee@nasa.gov
}

Received: 12 May 2020; Accepted: 22 May 2020; Published: 27 May 2020

\begin{abstract}
The global increase in air travel will require commercial vehicles to be more efficient than ever before. Advanced turbine hot section materials are a key technology required to keep fuel consumption and emission to a minimum. Ceramic matrix composites (CMCs) are the most promising material to revolutionize turbine hot section materials because of their excellent high-temperature properties. Rapid surface recession due to volatilization by water vapor is the Achilles heel of CMCs. Environmental barrier coatings (EBCs), which protect CMCs from water vapor, is an enabling technology for CMCs. The first CMC component entered into service in 2016 in a commercial engine, and more CMC components are scheduled to follow within the next few years. One of the most difficult challenges to CMC components is EBC durability because failure of EBC leads to a rapid reduction in CMC component life. Novel EBC chemistries, creative EBC designs, and robust processes are required to meet EBC durability challenges. Engine-relevant testing, characterization, and lifting methods need to be developed to improve EBC reliability. The aim of this Special Issue is to present recent advances in EBC technology to address current EBC challenges.
\end{abstract}

Keywords: EBC; CMC; oxidation; volatility; CMAS; thermomechanical; modeling

\section{Introduction}

Ceramic matrix composites (CMCs) are considered a game changer for gas turbine hot section materials because of their excellent high-temperature mechanical properties, oxidation resistance, and a light weight-one-third of nickel-based superalloys [1]. The introduction of CMCs enables a fuel burn reduction up to two percent-few other technology in today's pipeline have this much capability for fuel burn reduction [2]. Additionally, the light weight enables over 50 percent reduction in the turbine component weight [2].

$\mathrm{SiC} / \mathrm{SiC} \mathrm{CMC}$ derive their oxidation resistance from dense slow-growing silica $\left(\mathrm{SiO}_{2}\right)$ scale [3]. In combustion environments, however, the protective silica scale volatilizes by reacting with water vapor $\left(\mathrm{H}_{2} \mathrm{O}\right)$, leading to rapid CMC surface recession [4-9]. Alumina $\left(\mathrm{Al}_{2} \mathrm{O}_{3}\right)$ in oxide/oxide CMCs, although not as severe as silica, also suffers surface recession due to water vapor-induced volatilization [10]. External barrier coatings, known as environmental barrier coatings (EBCs), have been developed to protect CMCs from surface recession [11,12]. Over two decades of intense research and development led to the first EBC-coated CMC component-a high-pressure turbine CMC shroud-to enter service in the LEAP engine by CFM International (Cincinnati, Ohio) [2]. More CMC components, including combustor liners and high-pressure turbine vanes, are scheduled to follow in the near future [2].

One of the most difficult challenges to CMC components is EBC durability because failure of EBC leads to a rapid reduction in CMC component life. Key contributors to EBC failure include recession, oxidation, degradation by calcium-aluminum-magnesium silicates (CMAS) deposits, thermal and thermo-mechanical strains, particle erosion, and foreign object damage (FOD) [12,13]. Novel EBC chemistries, creative EBC designs, and robust processes as well as engine-relevant testing, characterization, and lifting methods are required to meet EBC durability and reliability challenges. 


\section{This Special Issue}

The nine research articles in this special issue present recent advances in EBC technology in the following areas: recession [14]; EBC chemistry and processes [15,16]; oxidation and recession [17]; oxygen permeability and EBC design [18]; CMAS thermal and mechanical properties [19]; CMAS infiltration modeling [20]; mechanical behavior in thermal shock [21]; and thermomechanical reliability: modeling and validation [22].

Smialek et al. [14] investigated the volatility of transient $\mathrm{TiO}_{2}$ and steady-state $\mathrm{Al}_{2} \mathrm{O}_{3}$ scales formed on $\mathrm{Ti}_{2} \mathrm{AlC}$ MAX phase ceramic in $1300^{\circ} \mathrm{C}$ high velocity (Mach $\left.0.3,100 \mathrm{~m} / \mathrm{s}\right)$ and high pressure $(6 \mathrm{~atm}$, $25 \mathrm{~m} / \mathrm{s}$ ) burner rig tests (BRT). Unlike metals, the ceramic was stable at $1300{ }^{\circ} \mathrm{C}$. Unlike $\mathrm{SiC}$ and $\mathrm{Si}_{3} \mathrm{~N}_{4}$, neither burner test produced a weight loss, unless pre-oxidized. Volatility of $\mathrm{TiO}_{2}$ was indicated by removal of Ti-rich oxide grains after BRT, while $\mathrm{Al}_{2} \mathrm{O}_{3}$ loss, not as pronounced as $\mathrm{TiO}_{2}$, was indicated by grain boundary etching and porosity. $\mathrm{Al}_{2} \mathrm{O}_{3}$ net weight loss was observed only on pre-oxidized samples, whose linear loss rate was about one-fifth of $\mathrm{SiO}_{2}$. $7 \mathrm{YSZ} \mathrm{TBC}$ on $\mathrm{Ti}_{2} \mathrm{AlC}$ survived for $500 \mathrm{~h}$ in the Mach 0.3 burner test with no indication of volatility or spalling.

Vaßen et al. [15] investigated various oxides as an EBC for both oxide/oxide and $\mathrm{SiC} / \mathrm{SiC}$ CMCs. The goal was to obtain dense and crystalline coatings. APS (atmospheric plasma spraying) $\mathrm{Y}_{2} \mathrm{O}_{3}, \mathrm{Gd}_{2} \mathrm{Zr}_{2} \mathrm{O}_{7}, \mathrm{Y}_{3} \mathrm{Al}_{5} \mathrm{O}_{12}$, and $\mathrm{Yb}_{2} \mathrm{Si}_{2} \mathrm{O}_{7}$ were investigated for oxide/oxide $\mathrm{CMCs}$, while $\mathrm{Y}_{2} \mathrm{SiO}_{5}$ and $\mathrm{Yb}_{2} \mathrm{Si}_{2} \mathrm{O}_{7}$ were investigated for $\mathrm{SiC} / \mathrm{SiC}$ CMCs. $\mathrm{Y}_{2} \mathrm{O}_{3}$ and $\mathrm{Gd}_{2} \mathrm{Zr}_{2} \mathrm{O}_{7}$ showed promising results for oxide/oxide CMCs: $\mathrm{Y}_{2} \mathrm{O}_{3}$ coating showed excellent adhesion due to the formation of chemical bond, while $\mathrm{Gd}_{2} \mathrm{Zr}_{2} \mathrm{O}_{7}$ coating required laser structuring of the CMC surface for good adhesion. APS $\mathrm{Y}_{2} \mathrm{SiO}_{5}$ required a heat treatment to obtain a desirable microstructure for $\mathrm{SiC} / \mathrm{SiC} \mathrm{CMCs}$. $\mathrm{Yb}_{2} \mathrm{Si}_{2} \mathrm{O}_{7}$ on $\mathrm{SiC} / \mathrm{SiC}$ CMCs was investigated using various thermal spray processes (APS, high velocity oxygen fuel (HVOF), very low pressure plasma spraying (VLPPS), and suspension plasma spraying (SPS)). APS coating was dense, but with a high degree of amorphous phase content. HVOF gave higher crystalline phase content than APS, but with some porosity. VLPPS coating gave the highest crystallinity and density. SPS gave a high degree of crystallinity, however segmental cracks could not be avoided. The study demonstrated the feasibility of various thermal spray methods besides APS for EBC processing.

Gatzen et al. [16] investigated $\mathrm{YAlO}_{3}$ as an EBC for $\mathrm{Al}_{2} \mathrm{O}_{3} / \mathrm{Al}_{2} \mathrm{O}_{3}$ CMCs using APS and VLPPS processes. APS resulted in a poor quality coating not suitable as an EBC. VLPPS, on the other hand, resulted in a coating with high crystallinity, high purity, and strong adhesion. The strong adhesion was attributed to the formation of chemical bonding due to the formation of $\mathrm{Y}_{3} \mathrm{Al}_{5} \mathrm{O}_{12}$ interfacial phase. The coating exhibited excellent thermal cyclic durability and CMAS resistance in laboratory testing, demonstrating its promise as an EBC for oxide/oxide CMCs.

Klemm et al. [17] investigated the oxidation and corrosion (water vapor-induced $\mathrm{SiO}_{2}$ volatilization) of two plasma-sprayed EBC systems $\left(\mathrm{Al}_{2} \mathrm{O}_{3} / \mathrm{YAG}\right.$ and $\left.\mathrm{Si} / \mathrm{Yb}_{2} \mathrm{Si}_{2} \mathrm{O}_{7}+\mathrm{SiC} / \mathrm{Yb}_{2} \mathrm{SiO}_{5}\right)$ on $\mathrm{SiC} / \mathrm{SiC}$ CMCs. Two EBC failure mechanisms were observed: spallation due to TGO-induced stresses and corrosion-induced gap at the TGO/EBC interface. $\mathrm{Al}_{2} \mathrm{O}_{3} / \mathrm{YAG} \mathrm{EBC}$, after burner rig test, suffered corrosion at the TGO/EBC interface and inside the $\mathrm{Al}_{2} \mathrm{O}_{3}$ bond coat. In $\mathrm{Si} / \mathrm{Yb}_{2} \mathrm{Si}_{2} \mathrm{O}_{7}+\mathrm{SiC} / \mathrm{Yb}_{2} \mathrm{SiO}_{5}$, TGO-induced failure was delayed because $\mathrm{SiC}$ particles in the intermediate layer oxidized first, forming a shell surrounding $\mathrm{SiC}$, and thereby served as a getter to reduce the permeation of oxidants $\left(\mathrm{O}_{2}\right.$, $\mathrm{H}_{2} \mathrm{O}$ ) through EBC. In the burner rig test, small pores developed in the intermediate layer due to $\mathrm{SiO}_{2}$ corrosion. The beneficial gettering function of $\mathrm{SiC}$ particles is temporary, disappearing when the $\mathrm{SiC}$ particles are fully consumed.

Kitaoka et al. [18] proposed an EBC design based on oxygen permeability calculations to improve oxygen shielding capability and phase stability of mullite coating in $\mathrm{Si} / \mathrm{mullite} \mathrm{EBC}$ for $\mathrm{SiC} / \mathrm{SiC}$ CMCs. Grain boundary (GB) diffusion of $\mathrm{O}$ ions in mullite, from high $\mathrm{PO}_{2}$ mullite surface to low $\mathrm{PO}_{2}$ mullite/Si interface, and simultaneous GB diffusion of $\mathrm{Al}$ ions in the opposite direction were calculated. Calculations projected: (i) mullite would decompose at the mullite/Si interface due to the outward $\mathrm{Al}$ diffusion and (ii) replacing the $\mathrm{Si}$ bond coat with the $\beta^{\prime}$-SiAlON bond coat would increase oxygen shielding capability of mullite-this is because the higher equilibrium $\mathrm{PO}_{2}$ for 
the oxidation of $\beta^{\prime}$-SiAlON to form $\mathrm{SiO}_{2}$ compared to the oxidation of $\mathrm{Si}$ to form $\mathrm{SiO}_{2}$ suppresses the inward $\mathrm{O}$ ion diffusion. Experiments confirmed the mullite decomposition at the mullite/Si interface and the improvement of mullite stability when the Si bond coat was replaced by $\beta^{\prime}-\mathrm{SiAlON}$. The latter is because $\beta^{\prime}-\mathrm{SiAlON}$ serves as a source for $\mathrm{Al}$.

Webster et al. [19] investigated the intrinsic thermal and mechanical properties of a volcanic ash glass obtained from the Eyjafjallajökull eruption of 2010. The properties studied include crystallization, melting temperature, CTE (coefficient of thermal expansion), modulus, hardness, and viscosity. The glass had a low propensity to crystallize in bulk form compared to synthetic sand glasses. Compared to sand glasses, the melting temperature and viscosity were higher, while the CTE and modulus were lower. The higher viscosity was attributed partly to a higher $\mathrm{SiO}_{2}$ and lower $\mathrm{CaO}$ content in the volcanic ash. Hardness was similar, but the indentation fracture toughness was about twice that of sand glasses, which was attributed to the presence of $\mathrm{Fe}_{3} \mathrm{O}_{4}$ crystallites in the volcanic ash. Understanding the variation of CMAS properties with composition can provide insight into CMAS/coating interactions, which can be highly valuable for the development of CMAS-resistant coatings.

Kabir et al. [20] developed a numerical approach for studying the infiltration kinetics of molten CMAS in EB-PVD TBCs. Detailed analyses of the infiltration kinetics were performed, and the results were verified by experimental infiltration depths of the feathery and coarse microstructures. The study identified key morphological features that are important for infiltration. The rate of longitudinal and lateral infiltration could be minimized by reducing the gap between columns and/or increasing the length of the feather arms. Long feather arms having a lower lateral inclination decreased the infiltration rate and, therefore, reduced the infiltration depth. A key takeaway is that the infiltration kinetics can be altered by careful tailoring of coating microstructure such as feather arm lengths and inter-columnar gaps.

Seo et al. [21] investigated crack formation, crack stability, and crack healing of Si/mullite, $\mathrm{Si} /\left(\right.$ mullite $\left.+\mathrm{Yb}_{2} \mathrm{SiO}_{5}\right)$, and $\mathrm{Si} / \mathrm{Y}_{2} \mathrm{SiO}_{5} \mathrm{EBCs}$ on $\mathrm{SiC} / \mathrm{SiC} \mathrm{CMC}$ s under thermal shock cycling between room temperature and $1350{ }^{\circ} \mathrm{C}$ in air. Mechanical behavior was determined before and after the test via indentation tests. EBCs developed mud cracks on the surface and unidirectional vertical cracks in the top coat after several thermal shock cycles. Mullite-based EBCs exhibited crack healing phenomena after 4000-5000 cycles, where cracks were covered and partially filled with a new phase. Post-test XRD showed only crystalline $\mathrm{Al}_{2} \mathrm{O}_{3}$ in addition to the $\mathrm{EBC}$ component phases, indicating that the new phase is likely amorphous. The nature of the new phase responsible for cracking healing was not fully understood yet. $\mathrm{Si} / \mathrm{Y}_{2} \mathrm{SiO}_{5} \mathrm{EBC}$ delaminated after 4000 cycles with no crack healing phenomena. After 5000 cycles, mullite-based EBCs showed no significant changes in modulus and hardness due to cracking healing, whereas $\mathrm{Y}_{2} \mathrm{SiO}_{5} \mathrm{EBC}$ showed a change from elastic to plastic behavior due to delamination.

Kawai et al. [22] investigated the thermomechanical stability of an as-processed EBC by comparing the ERR (energy release rate) for interfacial cracks calculated by FEM analysis and the interfacial fracture toughness determined experimentally. The EBC studied was (SiC/SiAlON/mullite/Yb disilicate-Yb monosilicate graded layer/Yb monosilicates with porous segmented structure). FEM showed thinner SiALON/thicker mullite combinations lower the initial ERR. Fracture in the interface fracture test occurred at the $\mathrm{SiC} / \mathrm{SiAlON}$ and $\mathrm{SiAlON} /$ mullite interfaces, indicating these interfaces are the weak link. ERR by FEM was sufficiently higher than the experimentally determined interfacial fracture toughness, indicating that as-processed EBC possesses sufficient thermomechanical reliability. As-processed EBC with 5-25 $\mu \mathrm{m}$ SiALON and mullite showed no interfacial delamination, confirming the thermomechanical reliability. This study considered only as-processed stresses. Further work is needed to assess the thermomechanical reliability in service environments by incorporating oxidation, CMAS, thermal cycling in temperature gradient, and mechanical stresses.

Funding: This research received no external funding.

Conflicts of Interest: The authors declare no conflict of interest. 


\section{References}

1. Anson, D.; Richerson, D.W. Progress in Ceramic Gas Turbine Development Vol. 2; van Roode, M., Ferber, M., Richerson, D.W., Eds.; ASME PRESS: New York, NY, USA, 2003; pp. 1-10.

2. Steibel, J. Ceramic matrix composites taking flight at GE Aviation. Am. Ceram. Soc. Bull. 2019, 98, 30-33.

3. Jacobson, N.S. Corrosion of silicon-based ceramics in combustion environments. J. Am. Ceram. Soc. 1993, 76, 3-28. [CrossRef]

4. Opila, E.J.; Hann, R. Paralinear oxidation of CVD SiC in water vapor. J. Am. Ceram. Soc. 1997, 80, 197-205. [CrossRef]

5. Smialek, J.L.; Robinson, R.C.; Opila, E.J.; Fox, D.S.; Jacobson, N.S. $\mathrm{SiC}$ and $\mathrm{Si}_{3} \mathrm{~N}_{4}$ scale volatility under combustor conditions. Adv. Compos. Mater. 1999, 8, 33-45. [CrossRef]

6. Robinson, R.C.; Smialek, J.L. $\mathrm{SiC}$ recession caused by $\mathrm{SiO}_{2}$ scale volatility under combustion conditions: I. Experimental results and empirical model. J. Am. Ceram. Soc. 1999, 82, 1817-1825. [CrossRef]

7. Opila, E.J.; Smialek, J.L.; Robinson, R.C.; Fox, D.J.; Jacobson, N.S. SiC recession caused by $\mathrm{SiO}_{2}$ scale volatility under combustion conditions: II. Thermodynamics and gaseous-diffusion model. J. Am. Ceram. Soc. 1999, 82, 1826-1834. [CrossRef]

8. $\quad$ More, K.L.; Tortorelli, P.F.; Ferber, M.K.; Walker, L.R.; Kiser, J.R.; Miriyala, N.; Brentnall, W.D.; Price, J.R. ASME Paper 99-GT-292; ASME TURBOEXPO: Indianapolis, IN, USA, 1999.

9. Ferber, M.K.; Lin, H.T.; Parthasarathy, V.; Brentnall, W.D. ASME Paper 99-GT-265; ASME TURBOEXPO: Indianapolis, IN, USA, 1999.

10. Opila, E.J.; Myers, D.L. Alumina volatility in water vapor at elevated temperatures. J. Am. Ceram. Soc. 2004, 87, 1701-1705. [CrossRef]

11. Lee, K.N.; Fritze, H.; Ogura, Y. Progress in Ceramic Gas Turbine Development Vol. 2; van Roode, M., Ferber, M., Richerson, D.W., Eds.; ASME PRESS: New York, NY, USA, 2003; pp. 641-664.

12. Lee, K.N. Environmental barrier coatings for CMCs. In Ceramic Matrix Composites; Bansal, N.P., Lamon, J., Eds.; Wiley: New York, NY, USA, 2015; pp. 430-451.

13. Lee, K.N. $\mathrm{Yb}_{2} \mathrm{Si}_{2} \mathrm{O}_{7}$ environmental barrier coatings with reduced bond coat oxidation rates via chemical modifications for long life. J. Am. Ceram. Soc. 2019, 102, 1507-1521. [CrossRef]

14. Smialek, J.L. Relative $\mathrm{Ti}_{2} \mathrm{AlC}$ scale volatility under $1300{ }^{\circ} \mathrm{C}$ combustion conditions. Coatings 2020, $10,142$. [CrossRef]

15. Vaßen, R.; Bakan, E.; Gatzen, C.; Kim, S.; Mack, D.E.; Guillon, O. Environmental barrier coatings made by different thermal spray technologies. Coatings 2019, 9, 784. [CrossRef]

16. Gatzen, C.; Mack, D.E.; Guillon, O.; Vaßen, R. $\mathrm{YAlO}_{3}-\mathrm{A}$ novel environmental barrier boating for $\mathrm{Al}_{2} \mathrm{O}_{3} / \mathrm{Al}_{2} \mathrm{O}_{3}$-ceramic matrix composites. Coatings 2019, 9, 609. [CrossRef]

17. Klemm, H.; Schönfeld, K.; Kunz, W. Delayed formation of thermally grown oxide in environmental barrier coatings for non-oxide ceramic matrix composites. Coatings 2020, 10, 6. [CrossRef]

18. Kitaoka, S.; Matsudaira, T.; Kawashima, N.; Yokoe, D.; Kato, T.; Takata, M. Structural stabilization of mullite films exposed to oxygen potential gradients at high temperatures. Coatings 2019, 9, 630. [CrossRef]

19. Webster, R.U.; Bansal, N.P.; Salem, J.A.; Opila, E.J.; Wiesner, V.L. Characterization of thermochemical and thermomechanical properties of Eyjafjallajökull volcanic ash glass. Coatings 2020, 10, 100. [CrossRef]

20. Kabir, M.R.; Sirigiri, A.K.; Naraparaju, R.; Schulz, U. Flow kinetics of molten silicates through thermal barrier coating: A numerical study. Coatings 2019, 9, 332. [CrossRef]

21. Seo, H.-I.; Kim, D.; Lee, K.S. Crack healing in mullite-based EBC during thermal shock cycle. Coatings 2019, 9, 585. [CrossRef]

22. Kawai, E.; Kakisawa, H.; Kubo, A.; Yamaguchi, N.; Yokoi, T.; Akatsu, T.; Kitaoka, S.; Umeno, Y. Crack initiation criteria in EBC under thermal stress. Coatings 2019, 9, 697. [CrossRef]

(C) 2020 by the author. Licensee MDPI, Basel, Switzerland. This article is an open access article distributed under the terms and conditions of the Creative Commons Attribution (CC BY) license (http://creativecommons.org/licenses/by/4.0/). 